\title{
Siamese Crocodile White Blood Cell Extract Inhibits Cell Proliferation and Promotes Autophagy in Multiple Cancer Cell Lines
}

\author{
Santi Phosri ${ }^{1,2}$, Nisachon Jangpromma ${ }^{2,3}$, Leng Chee Chang ${ }^{4}$, Ghee T. Tan ${ }^{4}$, Supakit Wongwiwatthananukit ${ }^{5}$, \\ Surachai Maijaroen ${ }^{2,6}$, Preeyanan Anwised ${ }^{2}$, Wisarut Payoungkiattikun ${ }^{2}$, and Sompong Klaynongsruang ${ }^{2,6 *}$ \\ ${ }^{1}$ Office of Education, Faculty of Engineering, Burapha University, Chonburi 20131, Thailand \\ ${ }^{2}$ Protein and Proteomics Research Center for Commercial and Industrial Purposes (ProCCI), Faculty of Science, Khon Kaen University, Khon \\ Kaen 40002, Thailand \\ ${ }^{3}$ Office of the Dean, Faculty of Science, Khon Kaen University, Khon Kaen 40002, Thailand \\ ${ }^{4}$ Department of Pharmaceutical Sciences, College of Pharmacy, University of Hawaii at Hilo, Hilo HI 96720, USA \\ ${ }^{5}$ Department of Pharmacy Practice, College of Pharmacy, University of Hawaii at Hilo, Hilo HI 96720, USA \\ ${ }^{6}$ Department of Biochemistry, Faculty of Science, Khon Kaen University, Khon Kaen 40002, Thailand
}

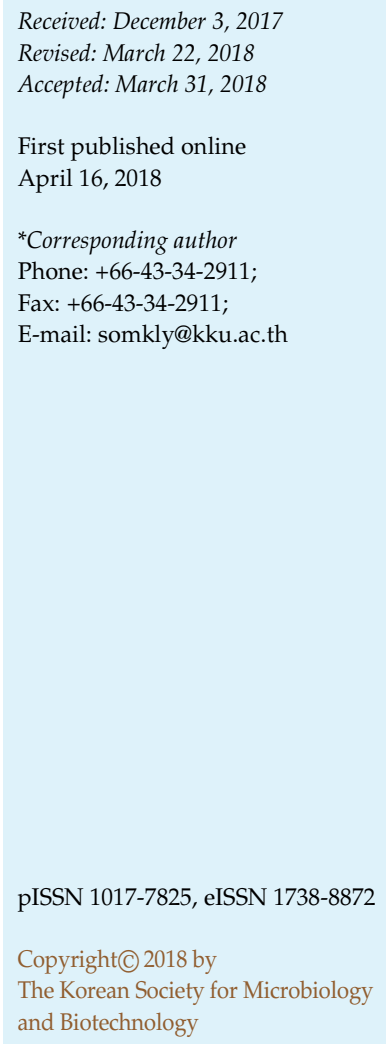

Cancer represents one of the most significant threats to human health on a global scale. Hence, the development of effective cancer prevention strategies, as well as the discovery of novel therapeutic agents against cancer, is urgently required. In light of this challenge, this research aimed to evaluate the effects of several potent bioactive peptides and proteins contained in crocodile white blood cell extract (cWBC) against LU-1, LNCaP, PC-3, MCF-7, and CaCo-2 cancer cell lines. The results demonstrate that $25,50,100$, and $200 \mu \mathrm{g} / \mathrm{ml} \mathrm{cWBC}$ exhibits a strong cytotoxic effect against all investigated cell lines $\left(\mathrm{IC}_{50} 70.34-101.0 \mu \mathrm{g} / \mathrm{ml}\right)$, while showing no signs of cytotoxicity towards noncancerous Vero and HaCaT cells. Specifically, cWBC treatment caused a significant reduction in the cancerous cells' colony forming ability. A remarkable suppression of cancerous cell migration was observed after treatment with cWBC, indicating potent antimetastatic properties. The mechanism involved in the cancer cell cytotoxicity of cWBC may be related to apoptosis induction, as evidenced by typical apoptotic morphology features. Moreover, certain cWBC concentrations induced significant overproduction of ROS and significantly inhibited the $S-\mathrm{G}_{2} / \mathrm{M}$ transition in the cancer cell. The molecular mechanisms of cWBC in apoptosis induction were to decrease Bcl-2 and XIAP expression levels and increase the expression levels of caspase-3, caspase- 8 , and p53. These led to a decrease in the expression level of the cell cycle-associated gene cyclin-B1 and the arrest of cell population growth. Consequently, these findings demonstrate the prospect of the use of cWBC for cancer therapy.

Keywords: Antitumor, breast cancer, colorectal cancer, Crocodylus siamensis, lung cancer, prostate cancer

\section{Introduction}

Population ageing poses a variety of problems that challenge public health worldwide. Extensive research has demonstrated that the number of adults aged 60 years and older will increase more rapidly in developing countries than in developed countries [1]. Ageing has been recognized as the first and foremost risk factor for noncommunicable diseases (NCDs), including tumors, heart diseases, hypertension, and diabetes [2]. The World Health Organization has concluded that deaths of over-60s caused by NCDs total over twice the number of those below 60 years of age. Cancer is regarded as a typical NCD, and represents one of the most serious health conditions on a global scale, 
accounting for 8.2 million cancer-related deaths and an estimated 14.1 million new cancer patients in the year 2012 alone, according to the GLOBOCAN 2012 report [3]. Worldwide, the most commonly diagnosed cancer types include 1.8 million cases of lung, 1.7 million cases of breast, 1.4 million cases of colorectal, and 1.1 million cases of prostate cancers [3]. Among these, prostate cancer is associated with the highest incidence rate of all cancer types in men, and with an estimated 307,000 deaths per year, it constitutes the principal cause of death, representing $6.6 \%$ of male cancer mortality in total [3]. Its incidence rate has increased by more than 25-fold worldwide, not least owing to the advent of readily available high-throughput cancer screening techniques. Although the cases of prostate cancer in East Asian countries is much lower than in Western countries, the incidence and mortality rates of prostate cancer have recently grown rapidly in some Asian countries [4].

A cancer's development is characterized by a multistep progression that eventually enables cancer cells to spread to other areas far distant from a given primary tumor mass, which often leads to metastasis. As a result, death in more than $90 \%$ of cancer patients is not caused by the primary tumor itself, but occurs as a result of the development of metastases affecting the vital organs of the patient [5]. With regard to the type and stage of tumor, some combination of surgery, radiotherapy, chemotherapy, or immunotherapy treatments can eradicate the tumor or slow its proliferation. Furthermore, such therapy techniques have been found to display a relatively short period of clinical life before being rendered ineffective, while other very potent medicines often exhibit severe side effects on healthy or normal cells and tissues $[6,7]$.

Consequently, the increasing cancer mortality rate has led many researchers to search for novel, potentially active compounds derived from natural products with potent anticancer activity. Within this wealth of structurally and functionally diverse compounds, bioactive molecules associated with innate immune systems especially may open up new strategies for anticancer therapy $[8,9]$. Antimicrobial peptides (AMPs) and proteins constitute an integral part of the innate immune mechanism for defending the host from pathogen infection [10] and are therefore interesting candidates for anticancer agents. The ability of certain AMPs called anticancer peptides (ACPs) to kill cancer cells is believed to derive from the positively charged AMPs playing a main role in the strong binding and selective disturbance of membranes [11]. The ACPs have two basic mechanisms, triggering apoptosis or necrosis in cancerous cells [12]. The killing, based on apoptosis through the mitochondrial lytic system and necrosis via cell membrane lysis, appears to be dependent on the presence of anionic lipids [12]. It is supported by several reports that cationic AMPs, which have effects on bacterial cells but no significant toxicity to healthy mammalian cells, exhibit a broad spectrum of cytotoxic properties against cancerous cells [11].

Crocodilians form an ancient group among the class of reptiles, and typically thrive in aquatic environments containing a high burden of infectious microbes [13]. Although violent fighting with other crocodiles or species occurs frequently, the resulting wounds and lesions appear to heal quickly and there are almost no symptoms from pathogen infections, in spite of the harsh natural conditions [14]. Furthermore, crocodiles rarely seem to show any evidence of cancer symptoms within their average span of life [15]. In the recent years, several studies have demonstrated a surprisingly broad range of biological activity for the blood of the Siamese crocodile (Crocodylus siamensis), including antibacterial [14, 16-18], antioxidant $[19,20]$, anti-inflammatory $[19,21]$, and wound healing activities [22]. Leukocytes (white blood cells; WBC), one of the major constituents of crocodile blood, belong to the family of effector cells in the innate immune mechanism, which act against pathogens by employing a variety of peptides that exhibit antimicrobial functions [16]. Although eosinophils, basophils, and natural killer cells in particular represent a source of antimicrobial molecules, a variety of other bioactive substances capable of destroying or inhibiting microbial pathogen growth are also expressed in leukocytes [23]. In our previous work, Siamese crocodile Leucrocin I-IV antibacterial peptides were isolated from leukocyte extracts [16]. Leucrocin I-IV showed strong antibacterial properties against Staphylococcus epidermidis, Salmonella typhi, and Vibrio cholerae. The targets for these four antimicrobial peptides were both outer and inner membranes of bacteria. This characteristic of AMPs is important in leading to the hypothesis that AMPs and ACPs share similar molecular principles for inhibiting the viability of cancer cells via cell membranes by electrostatic interactions, disrupting their function and resulting in the death of the cancer cells [10]. Hence, white blood cells derived from Siamese crocodile blood (cWBC) are considered an excellent source of naturally occurring active peptides, which are highly promising to serve as templates for the development of effective remedies for cancer. To determine the property of cWBC against multiple cancer cell lines, the experiment in the recent work was focused on functional analysis of the effects on the proliferation of human lung cancer cells (LU-1), human 
prostate cancer cells (LNCaP and PC-3), human breast cancer cells (MCF-7), and human colon cancer cells (CaCo-2). Then, the colony formation, migration, autophagy, ROS signal, and cell cycle progression were evaluated to explain the mechanism of the $\mathrm{cWBC}$ on cancer cell inhibition.

\section{Materials and Methods}

\section{Reagents}

Sulforhodamine B (SRB), trichloroacetic acid (TCA), Tris (tris[hydroxymethyl] amino methane), and propidium iodide (PI) were obtained from Sigma-Aldrich (USA). Fetal bovine serum (FBS), Dulbecco's modified Eagle's medium (DMEM), and penicillin/ streptomycin were obtained from Invitrogen (USA). Trypsin-EDTA was obtained from Mediatech (USA), 2',7'-dichlorodihydrofluorescein diacetate $\left(\mathrm{H}_{2} \mathrm{DCFDA}\right)$ was obtained from Biolegend (USA), and RNase A was purchased from Merck (Germany).

\section{Siamese Crocodile Blood Sample Collection}

Blood of crocodiles was purchased from Sriracha Moda Farm, Chonburi, Thailand. The whole blood was transferred into a bottle containing EDTA $(8 \mathrm{mg} / \mathrm{ml})$ and stored overnight at $4^{\circ} \mathrm{C}$. WBCs were collected after the cells in the whole blood sample were allowed to settle in the middle layer (buffy coat). The WBCs obtained were further extracted as described by Pata et al. [16]. Briefly, acetic acid $(10 \%(\mathrm{v} / \mathrm{v}))$ was added and mixed with the WBCs, followed by homogenization of the mixture using an ultrasonicator. The cWBC supernatant was obtained after centrifugation for $20 \mathrm{~min}$ at $12,000 \times g$ and subsequently kept at $-70^{\circ} \mathrm{C}$ until used in further experiments.

\section{Noncancerous and Human Cancerous Cell Line Culture}

African green monkey kidney cells (Vero), human keratinocytes (HaCaT), lung cancer cells (LU-1), prostate cancer cells (LNCaP and PC-3), breast cancer cells (MCF-7), and colorectal cancer cells $(\mathrm{CaCo}-2)$ were obtained from the American Type Culture Collection (ATCC, USA). Each cell line was grown on polystyrene tissue culture dishes and supplemented with DMEM containing $10 \%$ (v/v) heat-inactivated FBS, 100 units $/ \mathrm{ml}$ penicillin, and $100 \mu \mathrm{g} / \mathrm{ml}$ streptomycin and maintained at $37^{\circ} \mathrm{C}$ in an incubator with a $5 \% \mathrm{CO}_{2}$ humidified atmosphere. The cell lines were monitored daily and media were changed every 3-4 days. After attaining $90 \%$ confluence, the cancer cells were trypsinized from the dishes and resuspended in growth medium for further studies.

\section{Cell Viability by MTT Assay}

Assessment of the cytotoxicity of $\mathrm{cWBC}$ in the noncancerous (Vero and $\mathrm{HaCaT})$ cell lines was performed by the 3-(4,5dimethylthiazol-2-yl)-2,5-diphenyltetrazolium bromide (MTT) assay [9]. In brief, cells were seeded in 96-well plates at a final density of $1 \times 10^{4}$ cells/well and cultured overnight at $37^{\circ} \mathrm{C}$ in a $5 \% \mathrm{CO}_{2}$ incubator. Each cell line was then treated with $15.62-500 \mu \mathrm{g} / \mathrm{ml}$
cWBC, followed by the addition of $150 \mu \mathrm{l}$ of $0.5 \mathrm{mg} / \mathrm{ml}$ MTT solution to each well and incubation for $4 \mathrm{~h}$ at $37^{\circ} \mathrm{C}$. Afterwards, the medium was removed and the resulting MTT formazan product was solubilized in $100 \mu \mathrm{l}$ of DMSO. The absorbance values at $550 \mathrm{~nm}$ were measured using a microplate reader and the cell viability was evaluated by comparing the measured absorbance with the absorbance of untreated cells. All experiments were done at least in three replicates.

\section{Cytotoxicity Assessment by SRB Assay}

The in vitro cytotoxicity of cWBC was assessed using a procedure based on cell staining with SRB and measurement of the cellular protein content of adherent and suspended cultures in 96-well plates. The SRB assay employed was according to the experiment of Mehta and Pezzuto [24] with minor modifications. First, each cancer cell type was grown in 96-well plates $\left(5 \times 10^{4}\right.$ cells/well $)$ either in the absence or presence of $12.5-$ $200 \mu \mathrm{g} / \mathrm{ml} \mathrm{cWBC}$ and incubated for $72 \mathrm{~h}$. Each cell line was fixed by adding $100 \mu \mathrm{l} /$ well of ice cold $20 \%(\mathrm{w} / \mathrm{v})$ TCA at $4^{\circ} \mathrm{C}$ for $30 \mathrm{~min}$. After removing the fixative, the plate was washed with tap water 4 times and dried under air. Then, each cell was stained with $100 \mu \mathrm{l} /$ well of $0.4 \%(\mathrm{w} / \mathrm{v})$ SRB in $1 \%$ acetic acid for $30 \mathrm{~min}$ before rinsing off the unbound dye with $1 \%(\mathrm{v} / \mathrm{v})$ acetic acid 4 times and drying under air. The bound dye was solubilized with $10 \mathrm{mM}$ Tris base ( $\mathrm{pH} \mathrm{10;200 \mu l/well),} \mathrm{for} 20 \mathrm{~min}$ and the optical density was recorded at $531 \mathrm{~nm}$ using a Perkin Elmer 2030 multilabel reader. The cytotoxic effect of the compound was calculated using the following formula:

Percentage of inhibition $=100-\left(\mathrm{Abs}_{\text {test }}-\mathrm{Abs}_{\text {background }}\right) /\left(\mathrm{Abs}_{\text {control }}\right.$ $\left.-\mathrm{Abs}_{\text {background }}\right) \times 100$

The $50 \%$ inhibitory concentration $\left(\mathrm{IC}_{50}\right)$ was determined from dose-dependent curves.

\section{Morphological Observation of Apoptotic Cells by Phase-Contrast Inverted Microscopy}

The morphological study of apoptotic cells was performed according to the method of Chen et al. [25] with a few modifications. In brief, cells $\left(5 \times 10^{4}\right.$ cells/well $)$ were incubated for $48 \mathrm{~h}$ in the absence or presence of $25,50,100$, and $200 \mu \mathrm{g} / \mathrm{ml} \mathrm{cWBC}$ in a 24-well plate. After that, the medium was discarded and each cell line was washed once with PBS, and then fixed with methanol and stained with Giemsa. The morphology of the apoptotic cells was monitored using a phase-contrast inverted microscope at 200× magnification (Zeiss Axiovert 25; Zeiss, Germany).

\section{Colony Forming Assay}

A colony forming assay was constructed to investigate the longterm anticancer activity of cWBC. Therefore, each cancer cell type was seeded in a 24-well plate at about 400 cells/well for $24 \mathrm{~h}$, and subsequently treated with $25,50,100$, and $200 \mu \mathrm{g} / \mathrm{ml} \mathrm{cWBC}$ for $48 \mathrm{~h}$. Then, the medium was removed and the cells were continuously incubated in fresh medium at $37^{\circ} \mathrm{C}$ in $5 \%$ humidified $\mathrm{CO}_{2}$ for a 
duration of 10 days, during which the medium was changed once every 3 days. The cells were then rinsed with PBS and fixed for 15 min using methanol:acetic acid (3:1). Afterwards, each cell line was stained with $0.5 \%$ crystal violet for $20 \mathrm{~min}$ and then washed with PBS, and the number of colonies was counted manually using a stereo microscope, with a colony defined as consisting of at least 50 cells.

\section{Scratch Migration Assay}

A scratch migration assay was conducted to estimate the "wound-healing" propensity, following the protocol of Liang et al. [26]. Therefore, each cell type was grown in a 6-well plate to $80 \%$ confluence and a scratch was created using a $200 \mu \mathrm{l}$ pipette tip, followed by removal of floating cells and debris by washing with PBS. The cells were then photographed under a phase-contrast inverted microscope (time $=0$ ) and subsequently treated with 25 , 50,100 , and $200 \mu \mathrm{g} / \mathrm{ml} \mathrm{cWBC}$ or incubated in the absence of cWBC for $24 \mathrm{~h}$. Afterwards, the cells were gently rinsed with PBS, and the scratch wound area was photographed at the end of the incubation period of $24 \mathrm{~h}$ to count the number of cells that had migrated across the scratched lines. The percentage of control was expressed by assigning a value of $100 \%$ to the untreated wells. Since $\mathrm{cWBC}$ was found to exhibit the highest $\mathrm{IC}_{50}$ values against LNCaP cells, this cell line was selected for further experiments.

\section{Measurement of Intracellular Reactive Oxygen Species (ROS) Levels}

ROS levels were measured using $\mathrm{H}_{2}$ DCFDA following the protocol of Liu et al. [27]. In brief, LNCaP cells $\left(2 \times 10^{5}\right.$ cells $/$ well $)$ were treated with $\mathrm{cWBC}(25,50,100$, and $200 \mu \mathrm{g} / \mathrm{ml})$ for $24 \mathrm{~h}$. After that, the cells were collected and washed with PBS. The cell suspension in PBS was then incubated with $10 \mu \mathrm{M} \mathrm{H}_{2}$ DCFDA in the dark for $30 \mathrm{~min}$ at $37^{\circ} \mathrm{C}$ before measuring the ROS levels with a flow cytometer (BD FACSCanto II, USA). The ROS level was presented as the fluorescence of the treated cells relative to the fluorescence of the untreated (control) cells.

\section{Determination of Cell Cycle}

To analyze the distribution of LNCaP cells in different phases of the cell cycle, the DNA content of the cells was quantified by PI staining and flow cytometry. Briefly, LNCaP cells $\left(8 \times 10^{5}\right.$ cells/well $)$ were grown in a 6-well plate and incubated with 25, 50, 100, and $200 \mu \mathrm{g} / \mathrm{ml} \mathrm{cWBC}$ for $24 \mathrm{~h}$. After incubation, the cells were harvested, suspended in fresh medium, and centrifuged at $1,500 \times g$ for $5 \mathrm{~min}$. The cell pellets were washed with PBS and fixed by adding $500 \mu \mathrm{l}$ of $70 \%$ ice-cold ethanol overnight at $4^{\circ} \mathrm{C}$. Then, the cells were washed with PBS and incubated with $600 \mu$ of PBS (containing $100 \mu \mathrm{g}$ of PI and $50 \mu \mathrm{g}$ of RNase A) in the dark for $30 \mathrm{~min}$ at $37^{\circ} \mathrm{C}$. Afterwards, flow cytometric analysis was carried out using a BD FACSCanto II flow cytometer. The percentage of cells in different phases of the cell cycle was evaluated by MultiCycle DNA Content and Cell Cycle Analysis software.

\section{Real-Time PCR}

LNCaP cells were grown in a 6-well plate to a final density of $5 \times 10^{5}$ cell/well and left for $24 \mathrm{~h}$ in the absence or presence of cWBC at different concentrations $(25,50,100$, and $200 \mu \mathrm{g} / \mathrm{ml})$. Then, the cancer cells were trypsinized from the plate for further RNA extraction. Total RNA was extracted by a TRIzol reagent (Invitrogen, USA). The oligo(dT18) primer was used to initiate cDNA synthesis from $1 \mu \mathrm{g}$ of total derived RNA, following the RevertAid First-Strand cDNA synthesis kit manual (Fermentas, USA). The real-time PCR was carried out with the LightCycler 480 real-time PCR system (Roche, Switzerland) using SYBR Green PCR master mix (Roche, Switzerland). The primer sequences and annealing temperature of each gene are shown in Table 1 . The expression levels of $\mathrm{Bcl}-2$, XIAP, caspase- 3 , and caspase- 8 were used as markers to identify the induction of apoptosis in cells,

Table 1. Primers sequences for real-time PCR.

\begin{tabular}{|c|c|c|c|c|}
\hline Gene & Sequence $\left(5^{\prime} \rightarrow 3^{\prime}\right)$ & Annealing $\left({ }^{\circ} \mathrm{C}\right)$ & Product size (bp) & Reference sequence \\
\hline \multirow[t]{2}{*}{ Bcl-2 } & F_TGTGGCCTTCTTTGAGTTCGGTG & 63 & 114 & NM_000633.2 \\
\hline & R_GTGCCGGTTCAGGTACTCAGTCA & & & \\
\hline XIAP & R_TGCAACCAGAACCTCAAGTG & & & \\
\hline Caspase-3 & F_GTGGAATTGATGCGTGATGT & 55 & 113 & NM_001354777.1 \\
\hline \multirow[t]{2}{*}{ Caspase- 8} & F_AGAGTCTGTGCCCAAATCAAC & 55 & 78 & XM_005246894.3 \\
\hline & R_GCTGCTTCTCTCTTTGCTGAA & & & \\
\hline \multirow[t]{2}{*}{ Cyclin-B1 } & F_TTGATACTGCCTCTCCAAGCC & 55 & 122 & NM_001354844.1 \\
\hline & R_AGCTCCATCTTCTGCATCCAC & & & \\
\hline P53 & F_AGATAGCGATGGTCTGGC & 55 & 381 & LT739496.1 \\
\hline \multirow[t]{2}{*}{$\beta$-Actin } & F_GCATGGGTCAGAAGGATTCCT & 55 & 106 & NM_001101.4 \\
\hline & R_TCGTCCCAGTTGGTGACGAT & & & \\
\hline
\end{tabular}


whereas the expression levels of p53 and cyclin-B1 were used as markers to investigate cell cycle progression. The housekeeping gene $\beta$-actin was used as the normalized control to find out whether there was any change in the level of expression. The relative change in gene expression from the real-time quantitative PCR data was presented by the comparative $2^{-\Delta \mathrm{CT}}$ method [28].

\section{Statistical Analysis}

All data are expressed as the mean $\pm \mathrm{SD}$. A one-way analysis of variance followed by Dunnett's test and Duncan's multiple range tests were used to analyze the experimental data. Values of $p<0.05$ were statistically significant. All experiments were carried out at least in triplicate.

\section{Results}

\section{Effect of cWBC on the Viability of Noncancerous Cells}

Prior to the assessment of the putative anticancer ability of cWBC, the cytotoxicity of cWBC was evaluated towards noncancerous (Vero and $\mathrm{HaCaT}$ ) cell lines, for which the results are illustrated in Figs. 1A and 1B. The cWBC had no

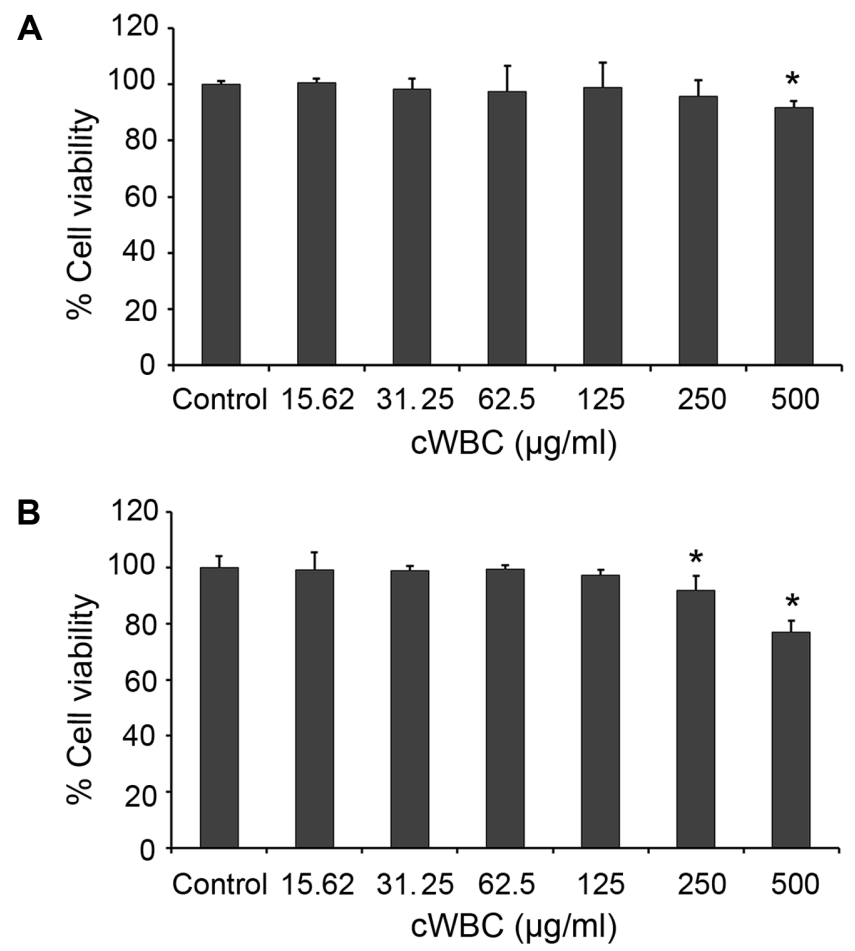

Fig. 1. Effect of Siamese crocodile white blood cell extract (cWBC) on the viability of noncancerous cells, measured by MTT assay.

(A) Vero and (B) HaCaT cells were incubated with cWBC at different concentrations $(15.62,31.25,62.5,125,250$, and $500 \mu \mathrm{g} / \mathrm{ml})$ for $24 \mathrm{~h}$. Each bar represents the mean $\pm \mathrm{SD}(n=8)$. *Significant at $p<0.05$. effect on Vero cell viability within a range of $15.62-250 \mu \mathrm{g} / \mathrm{ml}$ cWBC. When the concentration was increased to around $500 \mu \mathrm{g} / \mathrm{ml}$, a slight decrease in the percentage of cell viability was observed (Fig. 1A). In the same way, cWBC did not show any significant cytotoxic effect on the viability of $\mathrm{HaCaT}$ cells in a concentration range of $15.62-125 \mu \mathrm{g} / \mathrm{ml}$, whereas higher concentrations $(250 \mu \mathrm{g} / \mathrm{ml})$ of cWBC led to a slightly decreased percentage of viability (Fig. 1B).

\section{Effect of cWBC on the Viability of Cancerous Cells}

The anticancer efficiency of cWBC on different cancer cell lines was determined using the SRB method, measuring cellular protein content. A significant cytotoxic effect induced by cWBC was observed after $72 \mathrm{~h}$ of treatment, resulting in a concentration-dependent decrease of cell viability in all tested cancerous cells (Fig. 2). The $\mathrm{IC}_{50}$ values for LU-1, LNCaP, PC-3, MCF-7, and CaCo-2 were 101.0, 51.4, 101.05, 95.93, and $70.34 \mu \mathrm{g} / \mathrm{ml}$, respectively. At $100 \mu \mathrm{g} / \mathrm{ml}$ of cWBC, the proliferation of LU-1, LNCaP, PC-3, MCF-7, and CaCo-2 cells was significantly inhibited by $49.5 \%, 90.8 \%, 49.5 \%, 52.1 \%$, and 69.0\%, respectively (Fig. 2).

\section{Effect of cWBC on Cancer Cell Colony Formation}

The colony forming assay was carried out to evaluate the long-term effects of cWBC on the proliferation of LU-1, LNCaP, PC-3, MCF-7, and CaCo-2 cells. The colony count indicated that $\mathrm{cWBC}$ induced a dose-dependent decrease in the colony formation ability in all tested cell lines (Fig. 3A). Dramatic effects of cWBC on the colony formation ability were observed at a concentration of $100 \mu \mathrm{g} / \mathrm{ml}$ (in all tested cells), and the formation of colonies was found to be completely inhibited at $200 \mu \mathrm{g} / \mathrm{ml}$. Notably, $50 \mu \mathrm{g} / \mathrm{ml}$ cWBC resulted in almost complete inhibition of colony

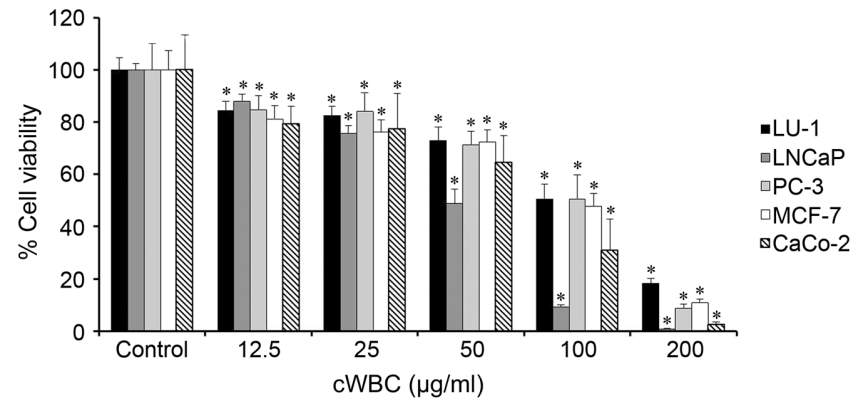

Fig. 2. Effects of cWBC on the viability of LU-1, LNCaP, PC-3, MCF-7, and CaCo-2 cells, determined by the SRB assay.

Cells were incubated with 12.5, 25, 50, 100, and $200 \mu \mathrm{g} / \mathrm{ml}$ of cWBC for $72 \mathrm{~h}$. Results are expressed as the percentage of control. Each bar represents the mean $\pm \mathrm{SD}(n=6) .{ }^{*} p<0.05$; significant difference from control (one-way ANOVA followed by Dunnett's test). 
A
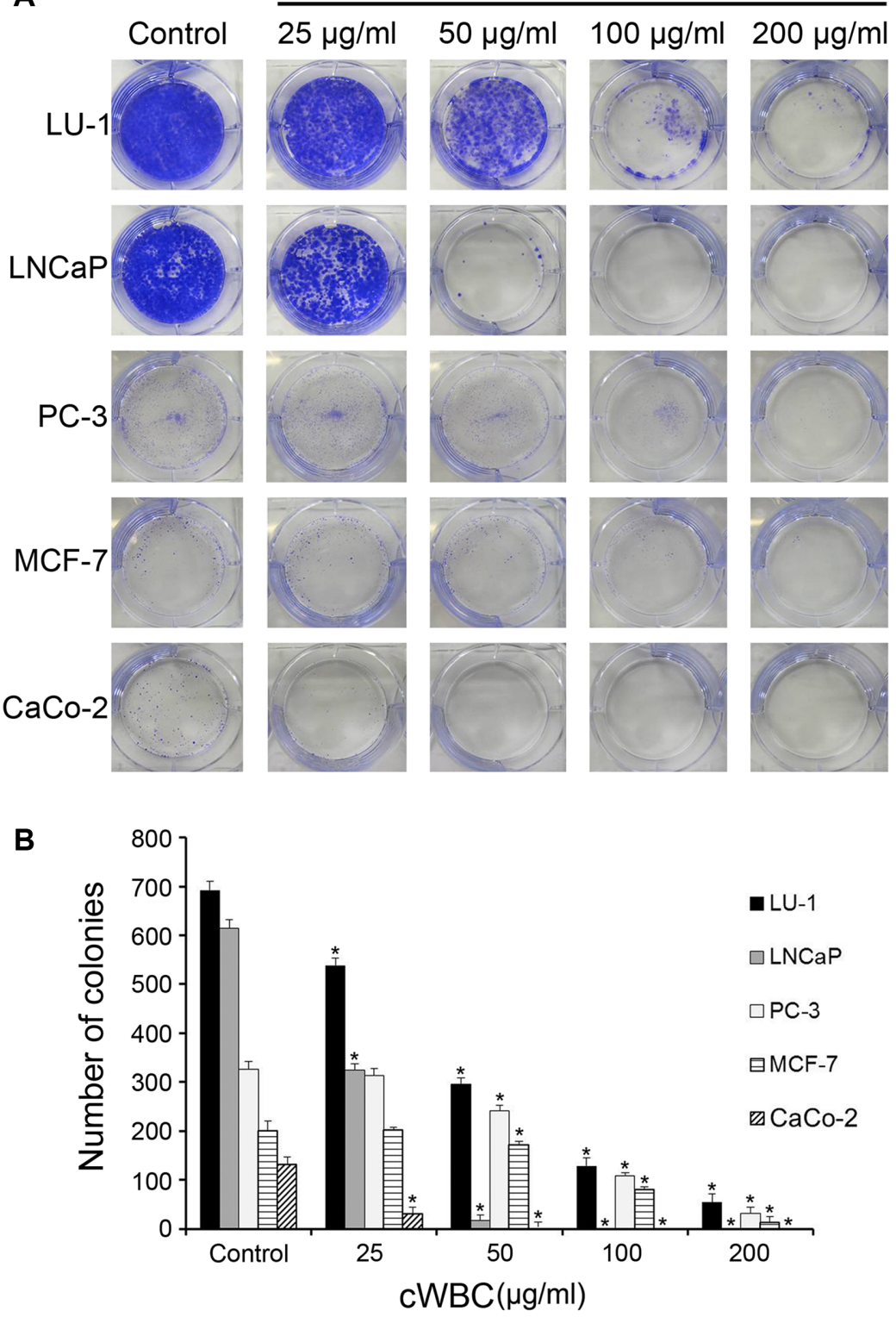

Fig. 3. Effect of cWBC on the colony formation ability of LU-1, LNCaP, PC-3, MCF-7, and CaCo-2 cells.

Cells were treated with cWBC at different concentrations (25,50,100, and $200 \mu \mathrm{g} / \mathrm{ml})$ for $48 \mathrm{~h}$. After $48 \mathrm{~h}$, the inhibitor was removed and the cells were grown in their respective culture media alone for 10 days. (A) Representative images of colonies in crystal violet. (B) Number of colonies counted. The data are presented as the mean $\pm \mathrm{SD}(n=3) .{ }^{*} p<0.05$; significant difference compared with the control group.

formation in the cases of $\mathrm{LNCaP}$ and $\mathrm{CaCo}-2$ cells. The total numbers of colonies for LU-1, LNCaP, PC-3, MCF-7, and CaCo-2 cells were found to be 127, 1, 108, 81, and 0 after challenge with $\mathrm{cWBC}$ at a concentration of $100 \mu \mathrm{g} / \mathrm{ml}$, respectively (Fig. 3B).

\section{Anticancer Cell Migration}

The scratch migration assay was conducted to assess the effect of cWBC on the cell migration ability (Fig. 4). Figs. 4A and $4 \mathrm{~F}$ display the migration and the corresponding percentages of migrated LU-1 cells after exposure to cWBC. After scratching, the remaining cells were exposed to $\mathrm{CWBC}$ at different concentrations and inspected microscopically over time, as the cells migrated to fill the damaged area. Migration of untreated LU-1, LNCaP, and PC-3 cells (Figs. 4A-4C) to heal the scratch occurred after $24 \mathrm{~h}$, 


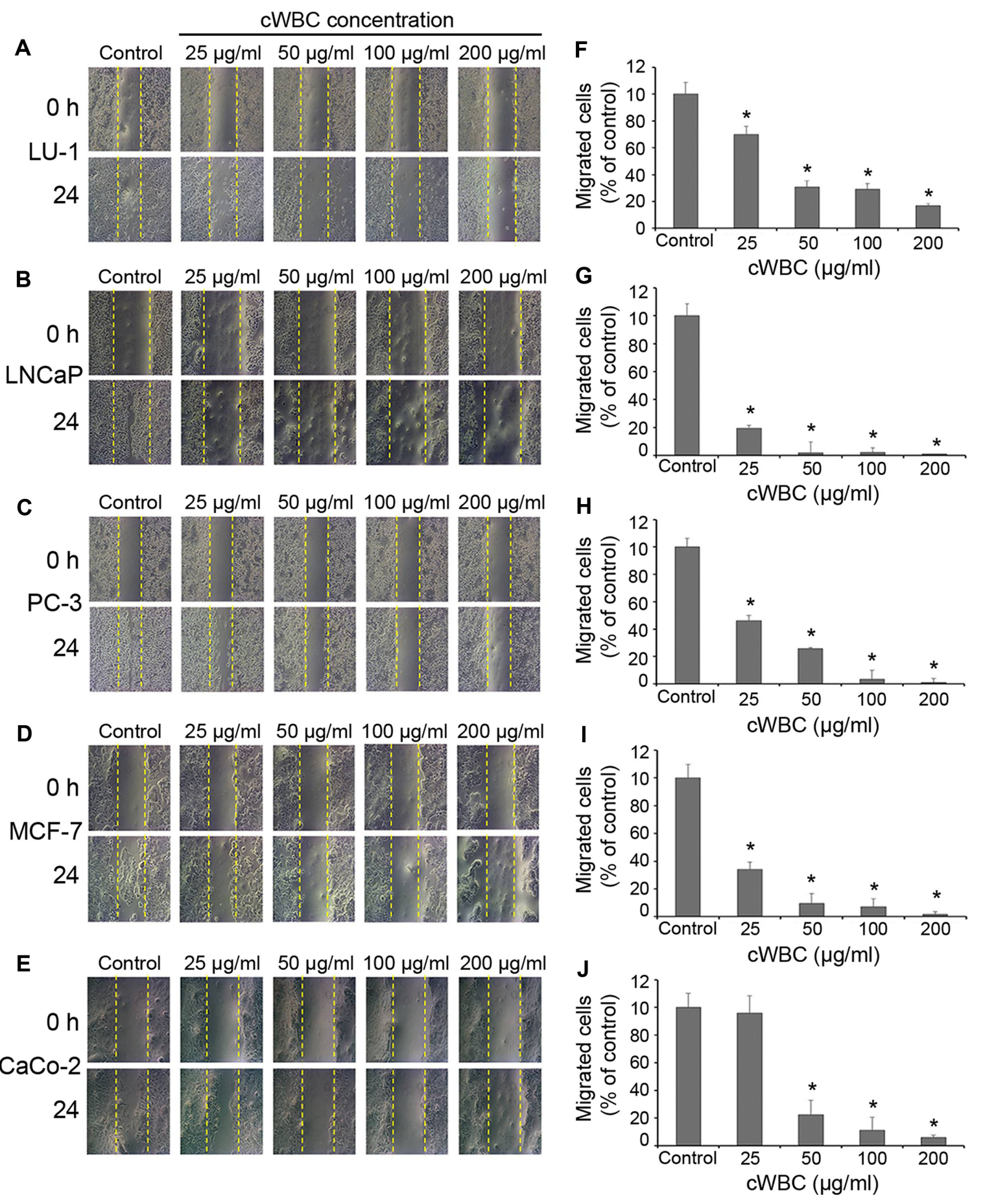

Fig. 4. Effect of cWBC on the migration of LU-1, LNCaP, PC-3, MCF-7, and CaCo-2 cells.

(A-E) Images showing inhibition of cWBC on LU-1, LNCaP, PC-3, MCF-7, and CaCo-2 cells, respectively. (F-J) Graphical representation of the percentage of migrated cells. The data are presented as the mean $\pm \operatorname{SD}(n=3) .{ }^{*} p<0.05$; significant difference compared with the control group.

whereas MCF-7 and CaCo-2 cells (Figs. 4D and 4E) did not completely cover the scratched area within the same timeframe. In the treated group, all tested cancerous cells demonstrated significant differences in the percentage of migrated cells compared with the respective controls. Specifically, treatment of LU-1, LNCaP, PC-3, and MCF-7 

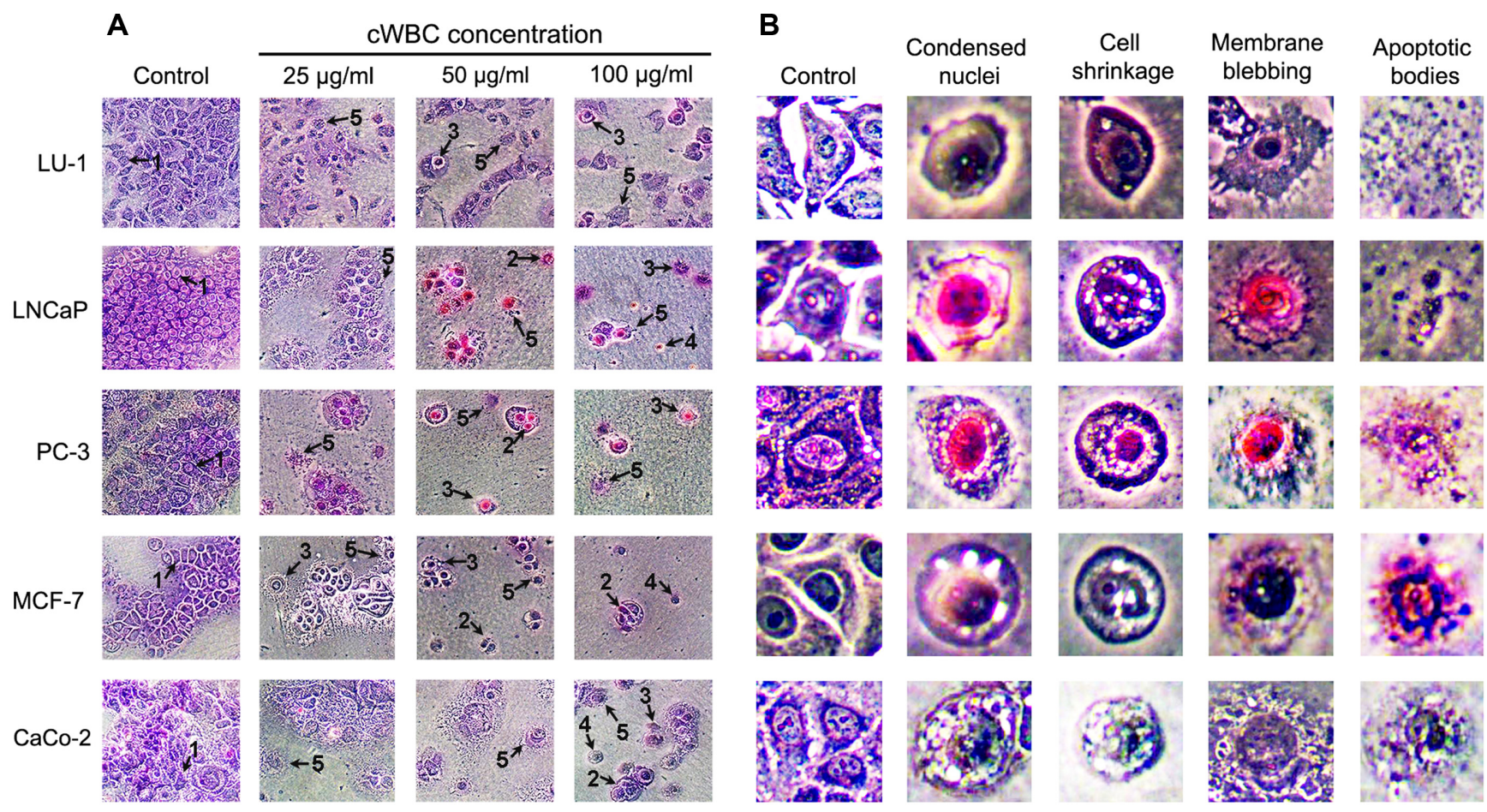

Fig. 5. Morphological appearance of LU-1, LNCaP, PC-3, MCF-7, and CaCo-2 cells treated with cWBC, under a phase-contrast inverted microscope.

Giemsa staining; 1: untreated control; 2: condensed nuclei; 3: cell shrinkage; 4: apoptotic bodies; and 5: membrane blebbing as evidence for apoptosis (A). The enlargement of each morphological hallmark of apoptosis in all cancer cells is shown in (B). Figures shown were obtained from at least three independent experiments with similar parameters.

cells with $25 \mu \mathrm{g} / \mathrm{ml}$ cWBC led to a significantly diminished quantity of migrated cells at 29.9\%, 80.7\%, 53.8\%, and $69.5 \%$ of the control, respectively. At a cWBC concentration of $50 \mu \mathrm{g} / \mathrm{ml}$, CaCo- 2 cells also showed a significant decrease in migrated cells at $77.6 \%$ of the control. Because they exhibited the greatest sensitivity to cWBC treatment, the LNCaP cells were selected for all subsequent studies.

\section{Effect of cWBC on the Morphological Changes of Cancer Cells}

Morphological changes of cells can be applied as an early indicator of responses to apoptotic stimuli [29]. Hence, after incubation with 25,50 , and $100 \mu \mathrm{g} / \mathrm{ml}$ of cWBC, morphological alterations in LU-1, LNCaP, PC-3, MCF-7, and $\mathrm{CaCo}-2$ cells were monitored in comparison with untreated cells used as controls (Fig. 5). The results indicate that challenge of cancer cells with cWBC for $48 \mathrm{~h}$ induces the formation of condensed nuclei (arrow No. 2), cell shrinkage (arrow No. 3), apoptotic body formation (arrow No. 4), and membrane blebbing (arrow No. 5), as compared with control cells (arrow No. 1; normal cell) (Fig. 5A). The enlargement of each morphological hallmark of apoptosis in all the cancer cells shown in Fig. 5B confirms that cWBC induced marked morphological changes in all the cancer cell lines investigated.

\section{Effect of cWBC on Reactive Oxygen Species Generation in Cells}

The induced ROS level in LNCaP cells was determined through interaction with a specific fluorescent dye, $\mathrm{H}_{2}$ DCFDA, which results in enhanced fluorescence intensity in response to reactive metabolite generation within the cells [30]. Fig. 6A demonstrates that the extent of ROS expression was significantly elevated, compared with the untreated cells $(p<0.05)$. Incubation with cWBC $(25,50,100$, and $200 \mu \mathrm{g} / \mathrm{ml})$ resulted in significantly elevated levels of ROS in a concentration-dependent manner, totaling up to 2.00, 2.64, 3.12 , and 4.29 times that of the control, respectively (Fig. 6B).

\section{Effect of cWBC on Cell Cycle Arrest}

To determine the effect of cWBC on $\mathrm{LNCaP}$ cell cycle phases, the intracellular DNA content was measured by 
A
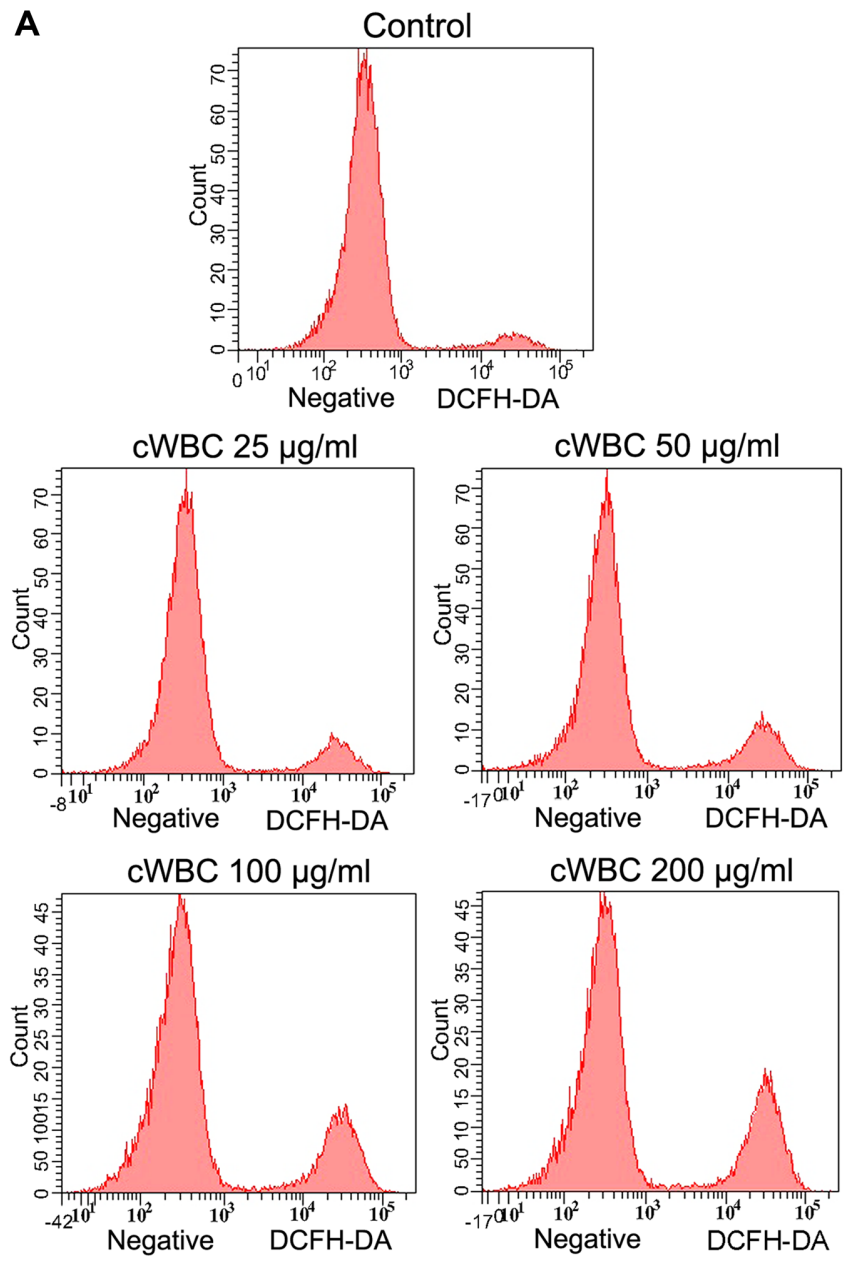

B

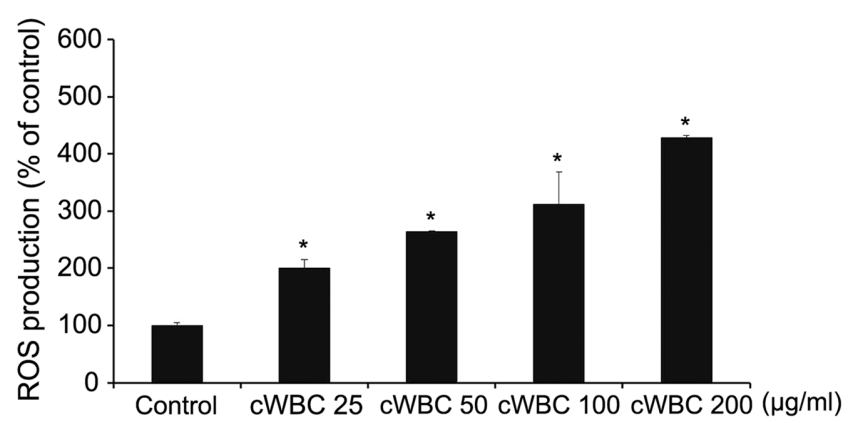

Fig. 6. Intracellular ROS generation in LNCaP cells induced by cWBC.

After treatment with cWBC for $24 \mathrm{~h}$, cells were incubated with $10 \mu \mathrm{M}$ $\mathrm{H}_{2}$ DCFDA for $30 \mathrm{~min}$ and then immediately subjected to flow cytometric analysis. (A) Chromatogram of flow cytometry. ROS generation was expressed as the ratio of relative fluorescence intensity compared with the control group (B). The data are presented as the mean $\pm \mathrm{SD}(n=3) .{ }^{*} p<0.05$; significant difference compared with the untreated cells (one-way ANOVA followed by Dunnett's test). flow cytometry (Fig. 7). Fractions of cells in the $S$ and $G_{2} / M$ phases were found to be significantly increased, together with significant reduction in the $G_{0} / G_{1}$ phases after $24 \mathrm{~h}$ of cWBC treatment (Fig. 7A). Interestingly, incubation with cWBC $(25,50,100$, and $200 \mu \mathrm{g} / \mathrm{ml})$ enhanced S phase arrest by $8.1 \pm 0.3 \%, 10.4 \pm 0.2 \%, 13.1 \pm 0.5 \%$, and $14.9 \pm 0.7 \%$, respectively (Fig. 7B). In addition, cWBC treatment at $25-$ $200 \mu \mathrm{g} / \mathrm{ml}$ for $24 \mathrm{~h}$ induced an increase in the number of cells in the $\mathrm{G}_{2} / \mathrm{M}$ phase, while the number of cells in the $\mathrm{G}_{0} / \mathrm{G}_{1}$ phase of the cell cycle declined when compared with the untreated control (Fig. 7B). These data demonstrate that the $\mathrm{CWBC}$ treatment inhibited $\mathrm{S}-\mathrm{G}_{2} / \mathrm{M}$ transition in the cells, leading to cell population growth arrest in LNCaP cells.

\section{Effect of cWBC on Expression Levels of Apoptotic and Cell Cycle Genes}

The expression levels of Bcl-2, XIAP, caspase-3, and caspase- 8 in $\mathrm{LNCaP}$ cells treated with various concentrations of $\mathrm{cWBC}$ were investigated to confirm the induction of the apoptosis process. As shown in Figs. 8A-8D, cWBC at all concentrations $(25-200 \mu \mathrm{g} / \mathrm{ml})$ strongly and significantly altered the apoptosis inhibitors, namely Bcl-2 and XIAP, in LNCaP cells by decreasing their expression level. Conversely, the treatment of $\mathrm{CWBC}$ inhibited the growth of LNCaP cells and led to cell death by dose-dependently increasing the expression level of caspase- 3 , caspase- 8 , and $\mathrm{p} 53$ genes. In addition, modifications of cell cycle genes by an increase in p53 and a decrease in cyclin-B1 expression were observed when treating cancer cells with various concentrations of cWBC (Figs. 8E and 8F).

\section{Discussion}

According to estimations of the World Health Organization, the number of new cancer diagnoses and cancer-related deaths increased to around 14.1 million and 8.2 million, respectively, in 2012, as compared with 12.7 million new cases and 7.6 million deaths in 2008 [3, 31]. Among these, breast, lung, prostate, and colon cancers have been associated with the highest prevalence worldwide, together accounting for about $50 \%$ of the global incidence burden [3]. Current cancer treatment is often accompanied with a number of detrimental side effects; for instance, cardiotoxicity and congestive heart failure in the case of doxorubicin [32]. In addition, the success rate of chemotherapy may be further limited by the development of drug resistance, rendering the development of alternative therapeutics an urgent task for pharmaceutical research.

Owing to the broad range of biological properties of 
A
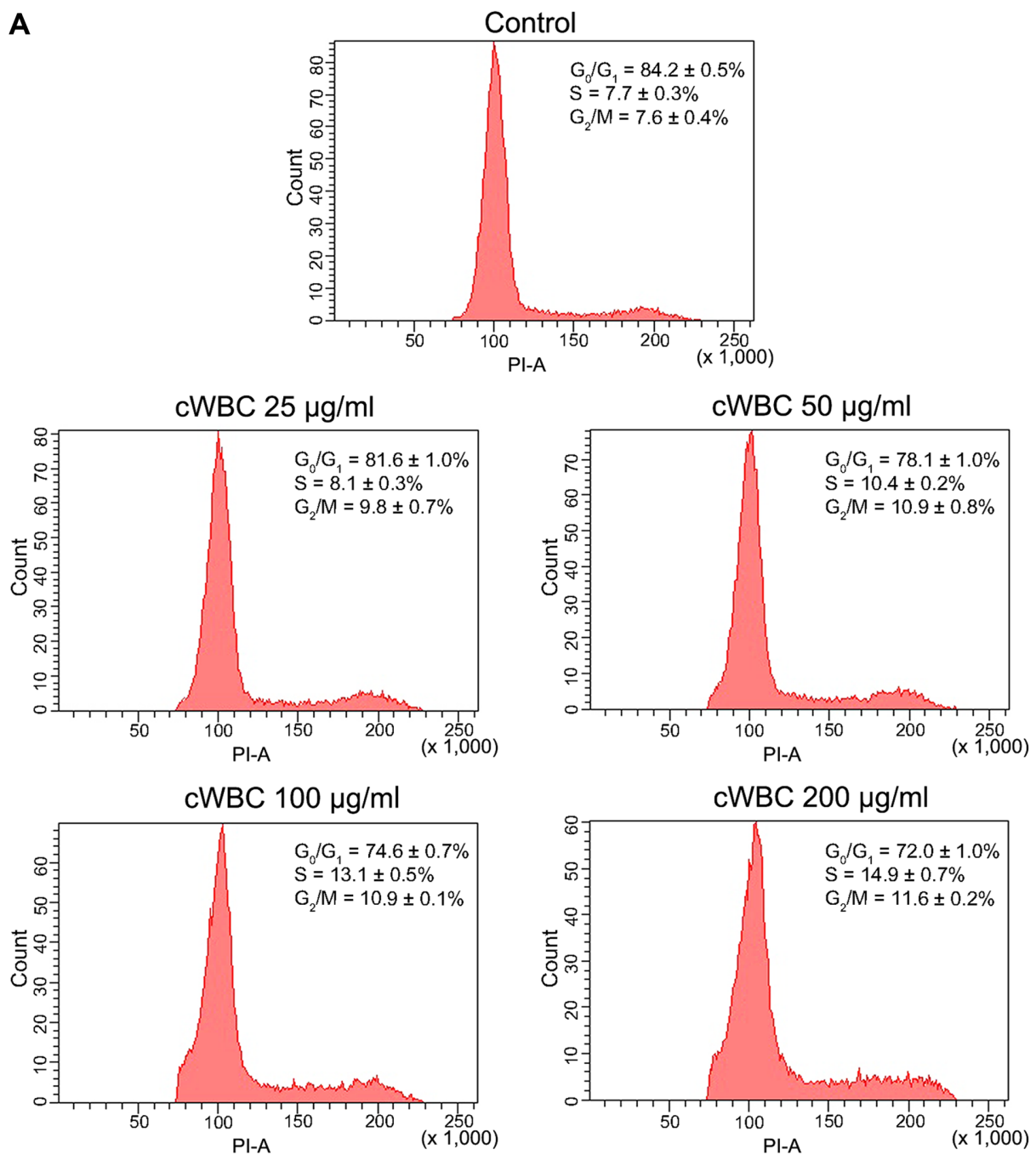

B

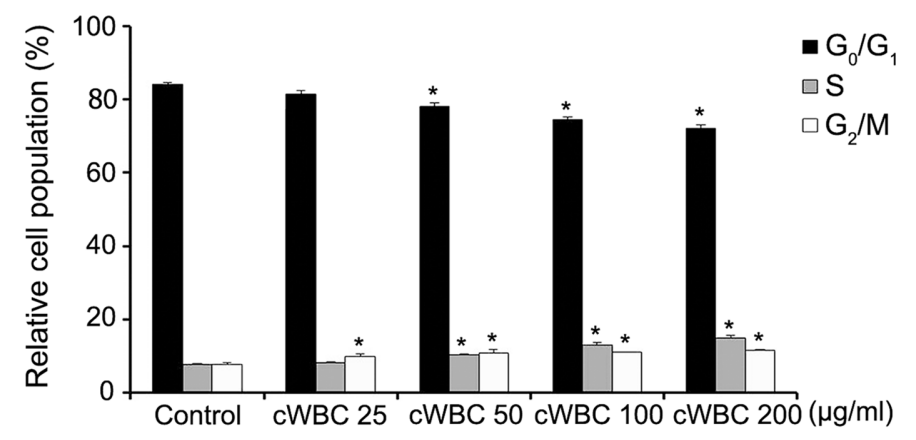

Fig. 7. Alterations of the cell cycle measured in $\mathrm{LNCaP}$ cells after treatment with cWBC.

(A) Panel showing the representative profiles of cell cycle status for cancer cells. (B) Graphical representation for $G_{0} / G_{1}, S$, and $G_{2} / M$ peak patterns of cancer cells treated with cWBC at different concentrations. Percentages of cell count of each cell cycle phase in each treatment group are shown as the mean $\pm \mathrm{SD}(n=3) .{ }^{*} p<0.05$; significant difference versus untreated cells (one-way ANOVA followed by Dunnett's test).

blood, the individual components of blood are considered an excellent source of naturally occurring, active peptides. Previously, the cationic peptides Leucrocin I-VI [16, 18,
33], cathelicidin [34], scolopendrasin VII [8], and hepcidin [35], have been isolated and were shown to exhibit potent antimicrobial activity. These small and generally amphipathic 

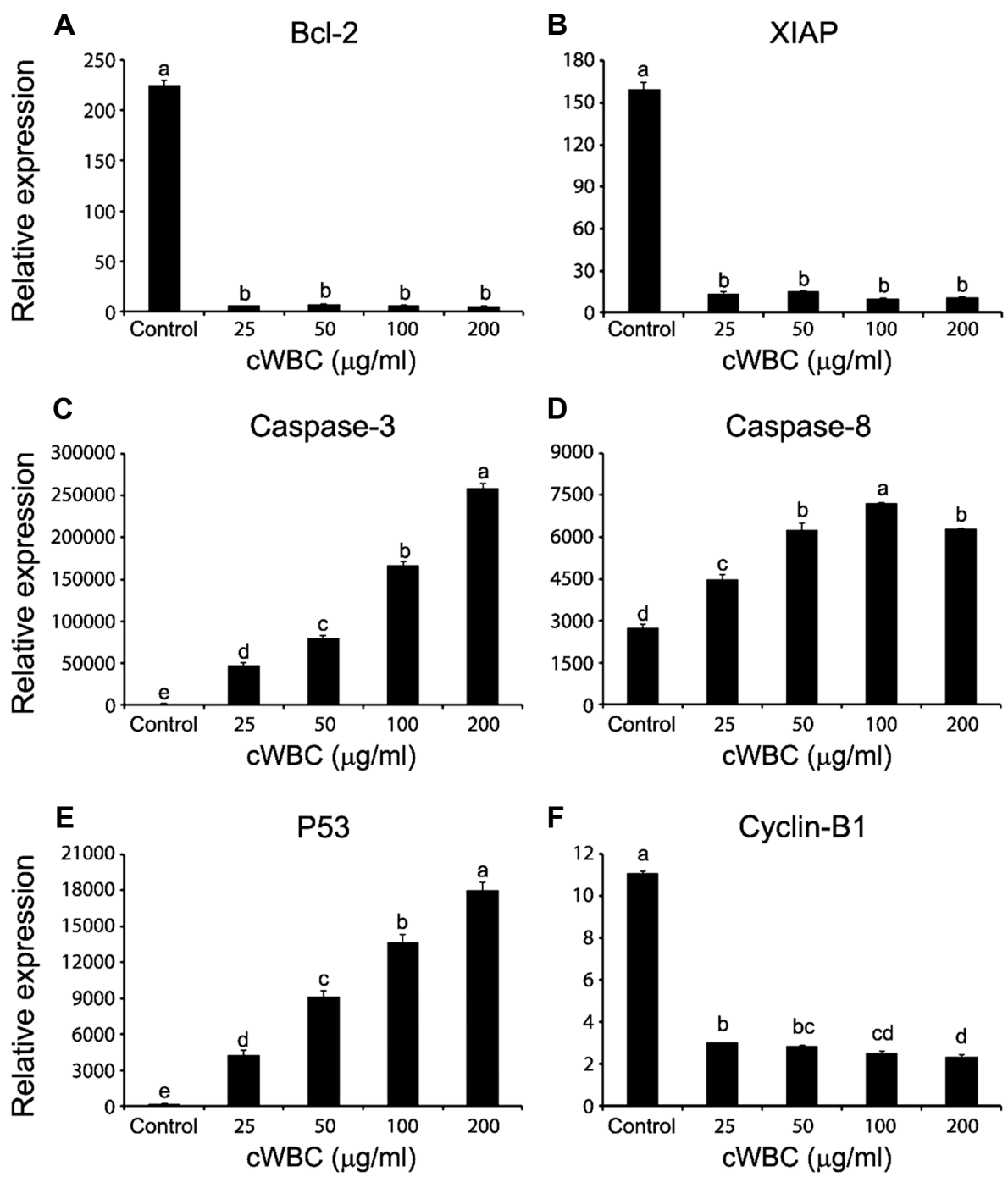

Fig. 8. Effect of cWBC on Bcl-2 (A), XIAP (B), caspase-3 (C), caspase-8 (D), p53 (E), and cyclin-B1 (F) mRNA expression in LNCaP cancer cells as determined by real-time PCR.

Each bar represents the mean and standard deviations in at least biological triplicates from the different experiments. Different letters (a-d) on the top of each bar indicate statistically significant differences $(p<0.05)$.

molecules constitute a pivotal mechanism of the immune defense with low antigenicity [36] and contain cationic and hydrophobic residues that facilitate the interaction with microbial membranes [37] through nonspecific interactions with membrane lipids [38]. Notably, the negative charge of the bacterial cell membrane surface is a property also shared by cancer cells [11], leading to the hypothesis that AMPs and ACPs might share similar molecular principles for activity and selectivity [10]. Recently, Patathananone et al. $[9,39]$ have reported WBC extract from C. siamensis exhibiting anticancer activity by inducing apoptosis, and inhibiting the migration and invasion process in HeLa cells. In light of the global threat of cancer towards human health, these findings motivated us to explore the anticancer activity of cWBC against human lung cancer (LU-1), prostate cancer (LNCaP, PC-3), breast cancer (MCF-7), and colorectal cancer (CaCo-2) cell lines in more detail.

The fundamental abnormality resulting in the development of cancer has been ascribed to the continual unregulated proliferation of cells [40]. Hence, the first part of this research was designed to elucidate the effect of cWBC treatment on the proliferation propensity of LU-1, LNCaP, PC-3, MCF-7, and CaCo-2 cancer cells using the SRB assay. The results demonstrate that cWBC exhibited dose-dependent 
anticancer property against several human cancerous cells with a degree of cytotoxicity in the order of LNCaP > CaCo-2 > MCF-7 > PC-3 > LU-1. Moreover, cWBC displayed potential long-term cytotoxic effects, as confirmed via colony formation assays in which treatment of cells with cWBC resulted in a largely similar inhibitory effect on the colony formation ability. Notably, cWBC displayed superior inhibitory ability on the colony formation of LNCaP cells in comparison with the other cancer cell lines. Therefore, the collected data indicate that cWBC shows a broad spectrum of antiproliferative activity against various types of cancerous cells, and further suggests cWBC to be useful for providing long-term inhibitory effects on cancer cell growth, which is in excellent agreement with the observed antiproliferative activities of cWBC against HeLa cancer cells reported by Patathananone et al. [39].

The ability to migrate from the primary tumor to a distant secondary site constitutes another characteristic property of cancer cells, and is generally regarded as one of the most problematic and harmful aspects of the disease [32]. Thus, a scratch cell migration assay was carried out to elucidate the possible influence of $\mathrm{CWBC}$ on cancer cell migration, revealing that $\mathrm{CWBC}$ was able to impede the migration of all investigated cancer cell lines (LU-1, LNCaP, PC-3, MCF-7, and $\mathrm{CaCo}-2)$ in a dose-dependent manner. It is speculated that this peculiar effect of cWBC may be associated with the reduction of the activity and protein expression levels of specific gelatinases (MMP-2, MMP-9) [9]. In this context, the disruption of vascular endothelial growth factors and integrin-signaling cascades by bioactive agents would also result in diminished MMP-2 and MMP-9 activity [9].

The ability to induce the programmed death of individual cells, a process also known as apoptosis, represents a significant mechanism for the eradication of damaged and mutated cells, whereas its dysregulation may lead to carcinogenesis [41]. Thus, apoptosis induction in cancer cells is regarded as an attractive strategy to combat inadvertent malignancy [41], and constitutes a key property of antitumor drug candidates [42]. Apoptosis itself is recognized as a general mode of cell death characterized by unique biochemical and morphological features [27]. Therefore, in order to assess the effect of cWBC treatment on the apoptotic process in cancer cells, the resulting alterations of cellular morphology were closely monitored by phasecontrast inverted light microscopy. Several morphological changes distinctive to apoptotic cells and commonly used for the identification of apoptosis $[43,44]$ were found to be induced by cWBC treatment of LU-1, LNCaP, PC-3, MCF-7, and $\mathrm{CaCo}-2$ cells; specifically, membrane blebbing, cell shrinkage, chromatin condensation, and the formation of apoptotic bodies. These findings closely resemble observations made by Patathananone et al. [39], who reported that $\mathrm{CWBC}$ can induce apoptosis in HeLa cells via both caspase-dependent and -independent pathways. Based on these findings, and in agreement with the antiproliferation (SRB assay) results, it is concluded that cWBC effectively induces cancer cell apoptosis.

Because prostate cancer ( $\mathrm{LNCaP}$ ) cells showed the highest susceptibility towards cWBC extract, LNCaP cells were selected as the representative cancer cell line for further elucidation of the mechanisms leading to cWBC treatmentinduced cell death. In this study, the molecular mechanistic demonstration of the ability of cWBC to induce apoptotic processes was associated with a decrease in expression of Bcl-2 and XIAP and an increase in expression of caspase-3 and caspase-8. Bcl-2 is a member of the protein family that plays a critical role in regulating apoptosis via a mitochondria-dependent pathway [45]. XIAP (X-linked inhibitor of apoptosis protein) plays a critical role of anchoring the inhibitor onto the caspase, which stops apoptotic cell death [41]. The results of real-time PCR showed a decrease of the anti-apoptotic Bcl-2 and XIAP mRNA expression level in $\mathrm{LNCaP}$ cells treated with $\mathrm{cWBC}$; hence the expression levels of caspase- 3 and caspase- 8 were significantly increased by $\mathrm{cWBC}$ at all treatment concentrations. Caspase-8 is involved in both extrinsic and intrinsic apoptotic signaling pathways, and functions via caspase-3 and Bid proteolytic cleavage [46]. The literature has demonstrated that in many human cancers, caspase- 8 is inactivated, leading to progression and resistance of cancer cells to chemotherapeutics [46]. Taken together, our data show that $\mathrm{CWBC}$ decreases the $\mathrm{Bcl}-2$ and XIAP expression levels and also increases caspase- 3 and caspase- 8 levels of gene expression, leading to the apoptotic cell morphological changes and dose-dependent inhibition of the proliferation of LNCaP.

Moreover, a pivotal role in the promotion of cellular apoptosis has been ascribed to excessive oxidative stress [47]. Although constituting vital signaling molecules involved in the regulation of diverse cellular functions, the profuse accumulation of ROS is known to induce oxidative stress, and has been associated with promoting a variety of different diseases, including the pathogenesis of inflammationrelated cancers [48, 49]. On the other hand, increased ROSderived stress in cancerous cells may also provide a biochemical basis for the development of novel therapeutic strategies exploiting these characteristics. Hence, by increasing ROS expression in the cell, suitable pharmacological agents 
may be able to stimulate the natural apoptotic process to kill cancer cells $[27,50,51]$. In a recent study, a significant overproduction of ROS was observed in LNCaP cells after treatment with $\mathrm{CWBC}$. This finding adds support to the assumption that sufficiently high ROS levels induce apoptosis by triggering pro-apoptotic signaling molecules within the tumor [51]. Furthermore, the results indicate that at high concentrations of $\mathrm{CWBC}$, the apoptotic process in LNCaP cells is correlated with an increase of ROS concentration in a dose-dependent manner, and cWBC may therefore exert a pro-oxidant effect in $\mathrm{LNCaP}$ cancer cells.

The cycle of cells is governed by a complex series of signaling pathways by which cell growth, DNA replication and cell division are controlled. The cell cycle regulates genomic replication and cell division [52], as well as the two main checkpoints, $G_{1} / S$ and $G_{2} / M$ transitions, which permit the cells to control any modification in DNA content. Checkpoint loss leads to genomic instability and carcinogenesis induction, whereas cell cycle arrest causes a stopping point in the cell cycle, where it no longer participates in processes related to cell duplication and division. Thus, the triggering of cell cycle arrest in cancer cell lines constitutes a crucial strategy in the most prevalent methods to inhibit or limit the spread of cancerous cells [53].

The recent work indicates that treatment with $\mathrm{cWBC}$ caused $\mathrm{S}$ and $\mathrm{G}_{2} / \mathrm{M}$ phase arrest in LNCaP cells, resulting in the initiation of apoptosis. The $\mathrm{CWBC}$-induced cell $\mathrm{S}$ phase arrest in the cell cycle may be associated with the reduction of DNA synthesis, by initiating DNA damage and causing replication fork arrest [54]. The cell cycle arrest induction at the $\mathrm{G}_{2} / \mathrm{M}$ phase by cWBC may involve an increase in p53 and a decrease in cyclin-B1 mRNA expression level (Figs. $8 \mathrm{E}$ and $8 \mathrm{~F}$ ). The literature reveals that the $\mathrm{G}_{2}$ checkpoint is regulated by activation of multiple processes that act together to inhibit the activity of the cyclin-B1/ Cdc2 kinase complex [45]. In addition, several researchers have indicated that p53 plays a crucial role in $G_{2}$ checkpoint regulation $[45,55]$. Regarding the activity to inhibit DNA replication, cationic peptides derived from crocodile leukocyte extract have previously been demonstrated to exhibit specific DNA binding activity depending on the charge of the peptide $[18,33]$. This evidence suggests that crocodile crude leukocyte extract contains a mixture of cationic peptides. After these crude cationic peptides bind to DNA, stopping or arresting at the $S$ phase occurs. This binding inhibits RNA synthesis and DNA replication in cells and in cell-free systems, which might result in the increase of the $\mathrm{G}_{2} / \mathrm{M}$ phase [56].

Taken collectively, the data gathered in this study provide strong evidence for the potent anticancer activity of cWBC, which is thought to be related to several active peptides contained in the extract. The experiments conducted demonstrate that $\mathrm{CWBC}$ exerts anticancer property against five human cancerous cells, namely LU-1, LNCaP, PC-3, MCF-7, and CaCo-2, by reducing the viability and colony formation ability of the cancer cells, inducing apoptosis, inhibiting cancer cell migration, increasing intracellular ROS levels, and inducing cell cycle arrest. Moreover, no evidence for cytotoxic effects against normal cells could be found. Recent publications have revealed that $C$. siamensis cWBC, and the purified peptides derived from it, contain antibacterial peptides with remarkable activity against various pathogenic bacterial strains [16]. The fundamental mechanisms of the antibacterial activity of cWBC and the purified antibacterial peptides contained may be closely related to the mechanisms associated with the observed anticancer activity. Basic differences exist between the cell membranes of normal cells and cancer cells, enabling the ability of certain antibacterial peptides to kill cancer cells (ACPs), but to spare healthy cells. In this context, electrostatic interactions between cationic ACPs and anionic cell membranes are supposed to be a crucial factor in the selective killing of cancer cells by these peptides. The membranes of cancer cells normally provide a net negative charge that is higher than the normal abundance of anionic molecules on the surface, such as phosphatidylserine in cellular membranes and glycosylated mucins. Moreover, the negative membrane potential of cancer cells may also contribute to the selective cytotoxic activity of ACPs [11]. Since cWBC did not display any toxicity towards the noncancerous Vero and $\mathrm{HaCaT}$ cell lines, it might serve as a useful starting material in the development of novel pharmaceuticals for the treatment of various types of cancers.

\section{Acknowledgments}

This present research was supported by the Protein and Proteomics Research Center for Commercial and Industrial Purposes (ProCCI), Faculty of Science, Khon Kaen University. We would like to thank the Department of Pharmaceutical Sciences, College of Pharmacy, University of Hawaii at Hilo, USA, for providing laboratory facilities and equipment to perform the anticancer assays. Our special thanks to Sriracha Moda Co. Ltd., Chonburi, Thailand, for providing the crocodile blood samples, as well as the Research Instrument Center, Khon Kaen University, for granting access to and support on the flow cytometer. 


\section{Conflict of Interest}

The authors have no financial conflicts of interest to declare.

\section{References}

1. Shrestha LB. 2000. Population aging in developing countries. Health Aff. (Millwood) 19: 204-212.

2. Yach D, Hawkes C, Gould CL, Hofman KJ. 2004. The global burden of chronic diseases: overcoming impediments to prevention and control. JAMA. 291: 2616-2622.

3. Ferlay J, Soerjomataram I, Dikshit R, Eser S, Mathers C, Rebelo M, et al. 2015. Cancer incidence and mortality worldwide: sources, methods and major patterns in GLOBOCAN 2012. Int. J. Cancer 136: E359-E386.

4. Chen R, Ren S, Yiu MK, Fai NC, Cheng WS, Ian LH, et al. 2014. Prostate cancer in Asia: a collaborative report. Asian J. Urol. 1: 15-29.

5. Hsu SC, Kuo CL, Lin JP, Lee JH, Lin CC, Su CC, et al. 2007. Crude extracts of Euchresta formosana radix inhibit invasion and migration of human hepatocellular carcinoma cells. Anticancer Res. 27: 2377-2384.

6. Wijesinghe WAJP, Jeon YJ, Ramasamy P, Wahid MEA, Vairappan CS. 2013. Anticancer activity and mediation of apoptosis in human HL-60 leukaemia cells by edible sea cucumber (Holothuria edulis) extract. Food Chem. 139: 326-331.

7. Pandey S, Walpole C, Cabot PJ, Shaw PN, Batra J, Hewavitharana AK. 2017. Selective anti-proliferative activities of Carica papaya leaf juice extracts against prostate cancer. Biomed. Pharmacother. 89: 515-523.

8. Lee JH, Kim IW, Kim SH, Kim MA, Yun EY, Nam SH, et al. 2015. Anticancer activity of the antimicrobial peptide scolopendrasin VII derived from the centipede, Scolopendra subspinipes mutilans. J. Microbiol. Biotechnol. 25: 1275-1280.

9. Patathananone S, Thammasirirak S, Daduang J, Chung J, Temsiripong Y, Daduang S. 2016. Inhibition of HeLa cells metastasis by bioactive compounds in crocodile (Crocodylus siamensis) white blood cells extract. Environ. Toxicol. 31: 1329-1336.

10. Gaspar D, Veiga AS, Castanho MA. 2013. From antimicrobial to anticancer peptides. a review. Front. Microbiol. 4: 294.

11. Hoskin DW, Ramamoorthy A. 2008 Studies on anticancer activities of antimicrobial peptides. Biochim. Biophys. Acta 1778: $357-375$.

12. Riedl S, Zweytick D, Lohner K. 2011. Membrane-active host defense peptides - challenges and perspectives for the development of novel anticancer drugs. Chem. Phys. Lipids 164: 766-781.

13. Wan QH, Pan SK, Hu L, Zhu Y, Xu PW, Xia JQ, et al. 2013. Genome analysis and signature discovery for diving and sensory properties of the endangered Chinese alligator. Cell
Res. 23: 1091-1105.

14. Preecharram S, Daduang S, Bunyatratchata W, Araki T, Thammasirirak S. 2008. Antibacterial activity from siamese crocodile (Crocodylus siamensis) serum. Afr. J. Biotechnol. 7: 3121-3128.

15. Jeyamogan S, Khan NA, Siddiqui R. 2017. Animals living in polluted environments are a potential source of anti-tumor molecule(s). Cancer Chemother. Pharmacol. 80: 919-924.

16. Pata S, Yaraksa N, Daduang S, Temsiripong Y, Svasti J, Araki T, et al. 2011. Characterization of the novel antibacterial peptide Leucrocin from crocodile (Crocodylus siamensis) white blood cell extracts. Dev. Comp. Immunol. 35: 545-553.

17. Kommanee J, Preecharram S, Daduang S, Temsiripong Y, Dhiravisit A, Yamada Y, et al. 2012. Antibacterial activity of plasma from crocodile (Crocodylus siamensis) against pathogenic bacteria. Ann. Clin. Microbiol. Antimicrob. 11: 22.

18. Yaraksa N, Anunthawan T, Theansungnoen T, Daduang S, Araki T, Dhiravisit A, et al. 2014. Design and synthesis of cationic antibacterial peptide based on Leucrocin I sequence, antibacterial peptide from crocodile (Crocodylus siamensis) white blood cell extracts. J. Antibiot. (Tokyo) 67: 205-212.

19. Phosri S, Mahakunakorn P, Lueangsakulthai J, Jangpromma N, Swatsitang P, Daduang S, et al. 2014. An investigation of antioxidant and anti-inflammatory activities from blood components of crocodile (Crocodylus siamensis). Protein J. 33: 484-492.

20. Theansungnoen T, Yaraksa N, Daduang S, Dhiravisit A, Thammasirirak S. 2014. Purification and characterization of antioxidant peptides from leukocyte extract of Crocodylus siamensis. Protein J. 33: 24-31.

21. Phosri S, Jangpromma N, Patramanon R, Kongyingyoes B, Mahakunakorn P, Klaynongsruang S. 2017. Protective effect of crocodile hemoglobin and whole blood against hydrogen peroxide-induced oxidative damage in human lung fibroblasts (MRC-5) and inflammation in mice. Inflammation. 40: 205-220.

22. Jangpromma N, Preecharram S, Srilert T, Maijaroen $S$, Mahakunakorn P, Nualkaew N, et al. 2016. In vitro and in vivo wound healing properties of plasma and serum from Crocodylus siamensis blood. J. Microbiol. Biotechnol. 26: 1140-1147.

23. Risso A. 2000. Leukocyte antimicrobial peptides: multifunctional effector molecules of innate immunity. J. Leukoc. Biol. 68: 785-792.

24. Mehta RG, Pezzuto JM. 2002. Discovery of cancer preventive agents from natural products: from plants to prevention. Curr. Oncol. Rep. 4: 478-486.

25. Chen J, Zhou M, Zhang Q, Xu J, Ouyang J. 2015. Anticancer effect and apoptosis induction of gambogic acid in human leukemia cell line K562 in vitro. Med. Sci. Monit. 21: 1604-1610.

26. Liang CC, Park AY, Guan JL. 2007. In vitro scratch assay: a convenient and inexpensive method for analysis of cell migration in vitro. Nat. Protoc. 2: 329-333.

27. Liu E, Du X, Ge R, Liang T, Niu Q, Li Q. 2013. Comparative toxicity and apoptosis induced by diorganotins in rat 
pheochromocytoma (PC12) cells. Food Chem. Toxicol. 60: 302-308.

28. Livak KL, Schmittgen TD. 2001. Analysis of relative gene expression data using real-time quantitative PCR and the $2^{-\Delta \mathrm{CT}}$ method. Methods 25: 402-408.

29. Häcker G. 2000. The morphology of apoptosis. Cell Tissue Res. 301: 5-17.

30. Ameziane El Hassani R, Dupuy C. 2013. Detection of intracellular reactive oxygen species $\left(\mathrm{CM}-\mathrm{H}_{2} \mathrm{DCFDA}\right)$. Bio Protoc. 3: e313.

31. Bray F, Ren JS, Masuyer E, Ferlay J. 2013. Global estimates of cancer prevalence for 27 sites in the adult population in 2008. Int. J. Cancer 132: 1133-1145.

32. Woo CC, Loo SY, Gee V, Yap CW, Sethi G, Kumar AP, et al. 2011. Anticancer activity of thymoquinone in breast cancer cells: possible involvement of PPAR- $\gamma$ pathway. Biochem. Pharmacol. 82: 464-475.

33. Anunthawan $T$, de la Fuente-Núñez C, Hancock REW, Klaynongsruang S. 2015. Cationic amphipathic peptides KT2 and RT2 are taken up into bacterial cells and kill planktonic and biofilm bacteria. Biochim. Biophys. Acta 1848: 1352-1358.

34. Barksdale SM, Hrifko EJ, van Hoek ML. 2017. Cathelicidin antimicrobial peptide from Alligator mississippiensis has antibacterial activity against multi-drug resistant Acinetobacter baumanii and Klebsiella pneumoniae. Dev. Comp. Immunol. 70: 135-144.

35. Hao J, Li Y-W, Xie M-Q, Li A-X. 2012. Molecular cloning, recombinant expression and antibacterial activity analysis of hepcidin from Simensis crocodile (Crocodylus siamensis). Comp. Biochem. Physiol. 163: 309-315.

36. Iwasaki T, Ishibashi J, Tanaka H, Sato M, Asaoka A, Taylor D, et al. 2009. Selective cancer cell cytotoxicity of enantiomeric 9-mer peptides derived from beetle defensins depends on negatively charged phosphatidylserine on the cell surface. Peptides 30: 660-668.

37. Brandenburg LO, Merres J, Albrecht LJ, Varoga D, Pufe T. 2012. Antimicrobial peptides: multifunctional drugs for different applications. Polymers 4: 539-560.

38. Arouri A, Dathe M, Blume A. 2009. Peptide induced demixing in PG/PE lipid mixtures: a mechanism for the specificity of antimicrobial peptides towards bacterial membranes? Biochim. Biophys. Acta 1788: 650-659.

39. Patathananone S, Thammasirirak S, Daduang J, Chung JG, Temsiripong Y, Daduang S. 2016. Bioactive compounds from crocodile (Crocodylus siamensis) white blood cells induced apoptotic cell death in HeLa cells. Environ. Toxicol. 31: 986-997.

40. Boohaker RJ, Lee MW, Vishnubhotla P, Perez JM, Khaled AR. 2012. The use of therapeutic peptides to target and to kill cancer cells. Curr. Med. Chem. 19: 3794-3804.

41. Dia VP, Krishnan HB. 2016. BG-4, a novel anticancer peptide from bitter gourd (Momordica charantia), promotes apoptosis in human colon cancer cells. Sci. Rep. 15: 33532.

42. Xiao JX, Huang GQ, Zhu CP, Ren DD, Zhang SH. 2007.
Morphological study on apoptosis Hela cells induced by soyasaponins. Toxicol. In Vitro 21: 820-826.

43. Syed Abdul Rahman SN, Abdul Wahab N, Abd Malek SN. 2013. In vitro morphological assessment of apoptosis induced by antiproliferative constituents from the rhizomes of Curcuma zedoaria. Evid. Based Complement. Alternat. Med. 2013: 257108.

44. Saraste A, Pulkki K. 2000. Morphologic and biochemical hallmarks of apoptosis. Cardiovasc. Res. 45: 528-537.

45. Zhang L, Zheng Y, Deng H, Liang L, Peng J. 2014. Aloperine induces $\mathrm{G}_{2} / \mathrm{M}$ phase cell cycle arrest and apoptosis in HCT116 human colon cancer cells. Int. J. Mol. Med. 33: 1613-1620.

46. Borhani N, Manoochehri M, Gargari SS, Novin MG, Mansouri A, Omrani MD. 2014. Decreased expression of proapoptotic genes Caspase-8- and BCL2-associated agonist of cell death $(B A D)$ in ovarian cancer. Clin. Ovarian Other Gynecol. Cancer 7: 18-23.

47. Nita M, Grzybowski A. 2016. The role of the reactive oxygen species and oxidative stress in the pathomechanism of the age-related ocular diseases and other pathologies of the anterior and posterior eye segments in adults. Oxid. Med. Cell. Longev. 2016: 3164734.

48. Sosa V, Moliné T, Somoza R, Paciucci R, Kondoh $H$, Lleonart ME. 2013. Oxidative stress and cancer: an overview. Ageing Res. Rev. 12: 376-390.

49. Umayaparvathi S, Meenakshi S, Vimalraj V, Arumugam M, Sivagami G, Balasubramanian T. 2014. Antioxidant activity and anticancer effect of bioactive peptide from enzymatic hydrolysate of oyster (Saccostrea cucullata). Biomed. Prev. Nutr. 4: 343-353.

50. Pelicano H, Carney D, Huang P. 2004. ROS stress in cancer cells and therapeutic implications. Drug Resist. Updat. 7: 97-110.

51. Xuan H, Li Z, Yan H, Sang Q, Wang K, He Q, et al. 2014. Antitumor activity of Chinese propolis in human breast cancer MCF-7 and MDA-MB-231 cells. Evid. Based Complement. Alternat. Med. 2014: 280120.

52. Collins K, Jacks T, Pavletich NP. 1997. The cell cycle and cancer. Proc. Natl. Acad. Sci. USA 94: 2776-2778.

53. Singh A, Fatima K, Singh A, Behl A, Mintoo MJ, Hasanain M, et al. 2015. Anticancer activity and toxicity profiles of 2-benzylidene indanone lead molecule. Eur. J. Pharm. Sci. 76: 57-67.

54. Yong WK, Ho YF, Malek SN. 2015. Xanthohumol induces apoptosis and S phase cell cycle arrest in A549 non-small cell lung cancer cells. Pharmacogn. Mag. 11: S275-S283.

55. Flatt PM, Pietenpol JA. 2000. Mechanisms of cell-cycle checkpoints: at the crossroads of carcinogenesis and drug discovery. Drug Metab. Rev. 32: 283-305.

56. Mancinelli L, De Angelis PM, Annulli L, Padovini V, Elgjo K, Gianfranceschi GL. 2009. A class of DNA-binding peptides from wheat bud causes growth inhibition, $G_{2}$ cell cycle arrest and apoptosis induction in HeLa cells. Mol. Cancer 8: 55. 